\title{
EFFECTS OF PLANTING DENSITYAND ORGANIC FERTILIZATION DOSES ON PRODUCTIVE EFFICIENCY OF CACTUS PEAR ${ }^{1}$
}

\author{
NALÍGIA GOMES DE MIRANDA E SILVA ${ }^{2 *}$, MÉRCIA VIRGINIA FERREIRA DOS SANTOS ${ }^{2}$, JOSÉ CARLOS \\ BATISTA DUBEUX JÚNIOR ${ }^{3}$, MÁRCIO VIEIRA DA CUNHA ${ }^{2}$, MÁRIO DE ANDRADE LIRA ${ }^{4}$, IVAN FERRAZ
}

\begin{abstract}
Cactus is crucial for the livestock of semi-arid regions in Brazil. This plant has shown the high productivity of forage, which is influenced by several management factors. This study aimed to evaluate the effect of organic fertilization doses $(20,40$ and $80 \mathrm{t} /$ ha of bovine manure/ha/two years) and planting densities $(20,40,80$ and 160 thousand plants/ha) on the productivity of cactus pear Clone IPA-20 (Opuntia ficus-indica Mill). At the Experimental Station of Caruaru at the Agronomic Institute of Pernambuco, IPA has conducted the experiment. The experimental design was randomized blocks, with split plot arrangements. Higher shoot productivity was observed with increased population density and the application of manure at 80 t ha-1two years- 1 with values of $61,90,117$ and $139 \mathrm{t} \mathrm{DM} \mathrm{ha}^{-1}$ two years ${ }^{-1}$ at densities of 20, 40, 80 and 160,000 plants ha-1. The planting density influenced the productivity of cladode-plant and root dry weight, showing exponential responses, with higher cladode-plant and roots weight by area observed with increased plant density. The efficiency of organic fertilization decreased with the increase in manure doses. For increase cactus productivity, $40 \mathrm{t}$ of bovine manure $\mathrm{ha}^{-1}$ two years $^{-1}$ for plantations with 160,000 plants/ha is recommended.
\end{abstract}

Keywords: Cactaceae. Bovine manure. Opuntia. Plants population.

\section{PRODUTIVIDADE E EFICIÊNCIA DA ADUBAÇÃO ORGÂNICA DA PALMA FORRAGEIRA SOB DIFERENTES DENSIDADES DE PLANTIO}

RESUMO - A palma tem grande importância para a pecuária da região semiárida do Brasil. Essa planta vem apresentando elevada produtividade de forragem, influenciada por vários fatores de manejo. Objetivou-se avaliar o efeito de doses de adubação orgânica (20, 40 e 80 t/ha de esterco bovino/ha/dois anos) e densidades de plantio (20, 40, 80 e $160 \mathrm{mil}$ plantas/ha) sobre a produtividade da palma forrageira Clone IPA-20 (Opuntia ficus indica Mill). O experimento foi conduzido na Estação Experimental de Caruaru, pertencente ao Instituto Agronômico de Pernambuco - IPA. O delineamento experimental foi em blocos casualizados, com arranjo de parcelas subdivididas. Verificou-se maior produtividade de parte aérea com o aumento da densidade populacional e aplicação de $80 \mathrm{t}$ de esterco/ha/dois anos, com valores de 61; 90; 117 e $139 \mathrm{t} \mathrm{MS/ha/dois} \mathrm{anos,}$ nas densidades de 20, 40, 80 e 160.000 plantas/ha. A produtividade do cladódio-planta e peso seco da raiz foram influenciados pela densidade de plantio, apresentando respostas exponenciais, tendendo a apresentar maior peso do cladódio planta e raízes por área com a elevação da densidade de plantio. A eficiência da adubação orgânica diminuiu com a elevação das doses de esterco. Recomenda-se para plantios com 160.000 plantas/ha aplicação de, no mínimo, $40 \mathrm{t}$ de esterco bovino/ha/dois anos para incremento na produtividade da palma.

Palavras-chave: Cactácea. Esterco bovino. Opuntia. População de plantas.

\footnotetext{
*Corresponding author

${ }^{1}$ Received for publication in $05 / 02 / 2014$; accepted in $05 / 11 / 2016$.

Paper Extracted from the doctoral thesis of the first author, funded by FACEPE

${ }^{2}$ Departament of Animal Science, Universidade Federal Rural de Pernambuco, Recife, PE, Brazil; naligiahta@hotmail.com, mercia.vfsantos@ufrpe.br, marcio.vieira.cunha@gmail.com.

${ }^{3}$ Departament of Animal Science, University of Florida, Marianna, FL, EUA; dubeux@ufl.edu.

${ }^{4}$ Instituto Agronômico de Pernambuco, Recife, PE, Brazil; mariolira@terra.com.br.

${ }^{5}$ Instituto Agronômico de Pernambuco, Caruaru, PE, Brazil; ivan.ferraz@ipa.br.
} 


\section{INTRODUCTION}

The Brazilian semiarid region covers $969,589.4 \mathrm{~km}^{2}$, which is equivalent to $69 \%$ of the Northeast and $13 \%$ of the country (MINISTÉRIO DA INTEGRAÇÃO NACIONAL, 2006). This ecosystem has high population density. Native Caatinga vegetation is used as a basis for pastoral activity (SÁ et al., 2004). However, forage yield for this vegetation is high.

In this sense, considering the carbon fixation cycle of cactus (Opuntia and Nopalea), which is called crassulacean acid metabolism (LIGUORI et al., 2013), these plants represent an important forage resource for the region (SAENZ, 2013), due to the plant's ability to withstand prolonged droughts (GEBRESAMUEL; GEBRE-MARIAM, 2012).

The yield of any cultivation is directly related to several factors that compose the cropping system. Planting spacing is a major factor in cactus establishing, since, in less dense crops, crop management is facilitated (Ramos et al., 2011). However, density tends to provide an increase in forage productivity. Dubeux Jr. et al. (2006) evaluated the cactus pear (Opuntia ficus-indica Mill.) under different planting densities ( 5 and 40,000 plants $\mathrm{ha}^{-1}$ ) and found that, in cropping areas with denser spacing, higher forage production was obtained, with values reaching $33.7 \mathrm{t} \mathrm{DM} \mathrm{ha}^{-1}$ two years $^{-1}$ with 40,000 plants ha ${ }^{-1}$.

Another important aspect of determining management for forage production is the use of fertilization, both organic and mineral. According to Rivera et al. (2006) fertilizers are utilized in the absence of organic fertilizer and point out that the element phosphorus is not restrictive to the growth of the cactus pear. On the other hand, Dubeux Jr. et al. (2006) reported that phosphorus levels below 11 ppm in soil restrict cactus growth. Fertilization increases the biomass production of cactus pear, enabling positive effects on productive system profitability (CUNHA et al., 2012).

Due to the importance of cactus pear for livestock and the need to assess the effects of management practices on crop production, this study aimed at evaluating the effect of organic fertilization doses and planting densities on productive characteristics of cactus pear clone IPA-20 and the efficiency of organic fertilization, in the Agreste of Pernambuco climate conditions.

\section{MATERIAL AND METHODS}

The experiment was conducted at the Experimental Station of Caruaru, at the Agronomic Institute of Pernambuco (IPA). The experimental station is situated in the Agreste region of the State, at $08^{\circ} 14^{\prime} 18^{\prime \prime}$ South latitude and $35^{\circ} 55^{\prime} 20^{\prime \prime}$ 'West longitude, and $537 \mathrm{~m}$ altitude. The average annual rainfall is $727.1 \mathrm{~mm}$. The soil classification of the experimental area is regolithic neosols (EMBRAPA, 2013).

The cactus Clone IPA-20 (Opuntia ficus-indica Mill.) was evaluated, established in March, 2003. After the establishment and before the beginning of the experimental period, cactus was fertilized and harvested in March 2005 and 2007, maintaining the primary cladodes.

The treatments were the combination of organic fertilization doses $(20,40$ and 80 t DM of bovine manure ha ${ }^{-1}$ two years $\left.{ }^{-1}\right)$ and different planting densities $(20,40,80$ and 160 thousand plants $\left.\mathrm{ha}^{-1}\right)$, obtained by the following plant spacing: $1.0 \mathrm{~m} \times 0.50 \mathrm{~m}, 1.0 \mathrm{~m} \times 0.25 \mathrm{~m}, 0.50 \mathrm{~m} \times 0.25 \mathrm{~m}$ and $0.50 \mathrm{~m} \times 0.125 \mathrm{~m}$, respectively. Table 1 shows the results of the organic fertilization analysis.

Table 1. Chemical analysis of the bovine manure used as fertilizer.

\begin{tabular}{|c|c|c|c|c|c|c|c|c|}
\hline $\mathrm{pH}$ & $\mathrm{P}^{*}$ & $\mathrm{Na}^{+}$ & $\mathrm{K}^{+}$ & $\mathrm{Ca}^{+2}$ & $\mathrm{Mg}^{+2}$ & $\mathrm{Al}^{+3}$ & $\mathrm{H}+\mathrm{Al}$ & $\mathrm{OC}^{1}$ \\
\hline water-1:2,5 & $\mathrm{mg} \mathrm{dm}^{-3}$ & \multicolumn{5}{|c|}{$\mathrm{cmol}_{\mathrm{c}} \mathrm{dm}^{-3}$} & $\mathrm{cmol}_{\mathrm{c}} \mathrm{dm}^{-3}$ & $\mathrm{~g} \mathrm{~kg}^{-1}$ \\
\hline 7.6 & 470.00 & 0.40 & 2.61 & 6.75 & 11.73 & 0.40 & 2.11 & 232 \\
\hline
\end{tabular}

Dry matter $(\%)=62 \%$

*Extractor de P- Mehlich, ${ }^{1}$ Organic carbon, ${ }^{2}$ Organic matter.

The experimental design was performed in randomized blocks, with subdivided plot arrangement, being organic fertilization the main portion and planting densities as subplot. The total and monthly rainfall data that corresponds the growth period from 2007 to 2009 are shown in Figure 1

Soil samples were collected just prior to the experiment in 2009 for the $0-20 \mathrm{~cm}$ layer. The results of soil fertility analysis are shown in Table 2 .

Table 2. Chemical analysis of the soil of the experimental area.

\begin{tabular}{|c|c|c|c|c|c|c|c|}
\hline $\mathrm{pH}$ & $\mathrm{P}^{*}$ & $\mathrm{Na}^{+}$ & $\mathrm{K}^{+}$ & $\mathrm{Ca}^{+2}+\mathrm{Mg}^{+2}$ & $\mathrm{Al}^{+3}$ & $\mathrm{H}+\mathrm{Al}$ & $\mathrm{OM}^{2}$ \\
\hline water-1:2,5 & $\mathrm{mg} \mathrm{dm}^{-3}$ & \multicolumn{4}{|c|}{$\mathrm{cmol}_{\mathrm{c}} \mathrm{dm}^{-3}$} & $\mathrm{cmol}_{\mathrm{c}} \mathrm{dm}^{-3}$ & $\mathrm{~g} \mathrm{~kg}^{-1}$ \\
\hline 4.2 & 4.00 & 0.57 & 0.26 & 3.00 & 0.50 & 4.19 & 4.20 \\
\hline
\end{tabular}

Dry matter $(\%)=61.50 \%$

*Extrator de P- Mehlich, ${ }^{1}$ Organic carbon, ${ }^{2}$ Organic matter. 


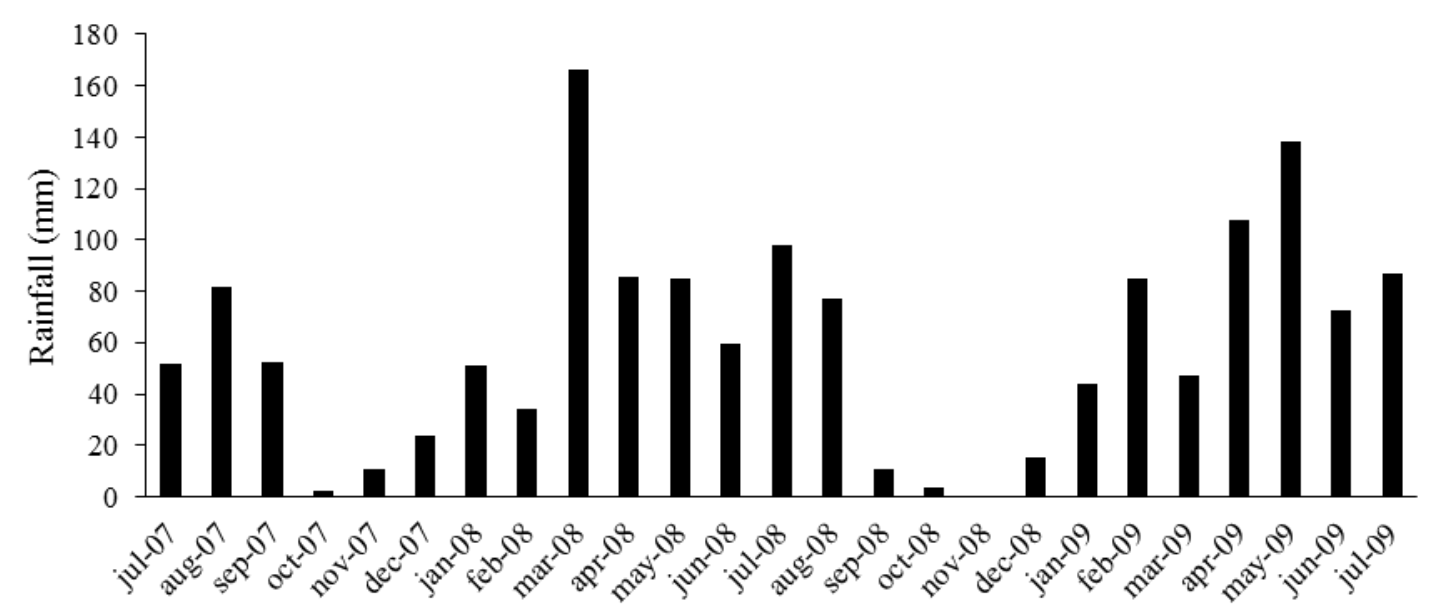

Months

Figure 1. Monthly rainfall during the growth of cactus pear sward.

The experimental area consisted of $815 \mathrm{~m}^{2}$ and contained three blocks, each with 16 subplots. Each subplot had $4 \mathrm{~m}$ width and $4 \mathrm{~m}$ length, totaling $16 \mathrm{~m}^{2}$, which were $1 \mathrm{~m}$ spaced, with $2 \mathrm{~m}$ width $\times 3 \mathrm{~m}$ length area.

The harvest was performed in July, 2009. Harvesting involved removing the cladode-plant with its root system from the soil. Productivity, organic fertilization efficiency, cladode-plant productivity and dry weight of roots were evaluated.

The organic fertilization efficiency was obtained by cactus productivity division ( $\mathrm{t} \mathrm{DM} \mathrm{ha}^{-1}$ ) according to the dose of organic fertilization. To evaluate and obtain cladode-plant weight and root system data as well as the green and dry weights of all cladodes/order, a scale with $10-\mathrm{kg}$ maximum capacity was used. Thus, besides cladode-plant, every cladode of first, second, third and fourth orders at two years of regrowth were weighed.

The root system of cladode plants was removed from a $40-\mathrm{cm}$ depth. After the cladode plant harvest and its respective root system, their separation was performed, followed by the root system washing in running water for complete removal of soil particles adhered to the roots. Subsequently, samples of the cladode-plant, cladodes per order and roots were placed in forced circulation at $55^{\circ} \mathrm{C}$ until weight remained constant to determine dry weight.

The statistical model used was $Y_{i j k}=\mu+C_{i}+e_{i j}+P_{k}+\left(C^{*} P\right)_{i k}+\varepsilon_{i j k}$, where $\mathrm{Y}_{i j k}$ represents the average response of fertilization $i$, replication $\mathrm{j}$, and planting density $\mathrm{k}$; $\mathrm{C} i$ is the organic fertilization and $\mathrm{P}_{k}$ the planting densities. Interactions $(\mathrm{C} * \mathrm{P})$ were considered as fixed effects. Random effects include the error of the main portion $\left(\mathrm{e}_{\mathrm{ij}}\right)$ and subplot error $\left(\varepsilon_{\mathrm{ijk}}\right)$.

The analysis of variance was conducted using Proc-mixed SAS software (SAS, 1999). When the F test was significant $(\mathrm{P}<0.05)$ regression analysis was performed by Sigmaplot software, version 12.

\section{RESULTS AND DISCUSSION}

There was significant effect $(\mathrm{P}<0.05)$ from the interaction between fertilization and planting densities on dry matter yield of cactus pear (Figure 2). It was possible to determine increased productivity with enhanced organic fertilization doses and planting densities, except for the fertilization of $20 \mathrm{t}$ of bovine manure ha ${ }^{-1}$ two years ${ }^{-1}$.

The increase in productivity with the use of organic fertilization was expected, since this culture, as reported by Almeida et al. (2012), responds positively to fertilization. This fact is derived from the gradual release of a larger flow of nutrients to plants, especially at higher doses of organic fertilization. Moreover, organic fertilizer may have promoted improvements in soil such moisture retention, improvement in nutrient utilization, among other benefits.

The improvements promoted by organic fertilizer are changes in the soil's physical properties beyond aggregate formatting. This increases the aeration and the water retention capacity. At the same time, it increases the cation exchange (CEC) of the medium, i.e. cationic nutrients $\mathrm{Ca}, \mathrm{Mg}$ and $\mathrm{K}$ become available to roots in larger amounts and longer time. Such improvements favor shoot and root system growth in cactus pear (PEIXOTO et al., 2006; MATALLO JR. et al., 2002). 

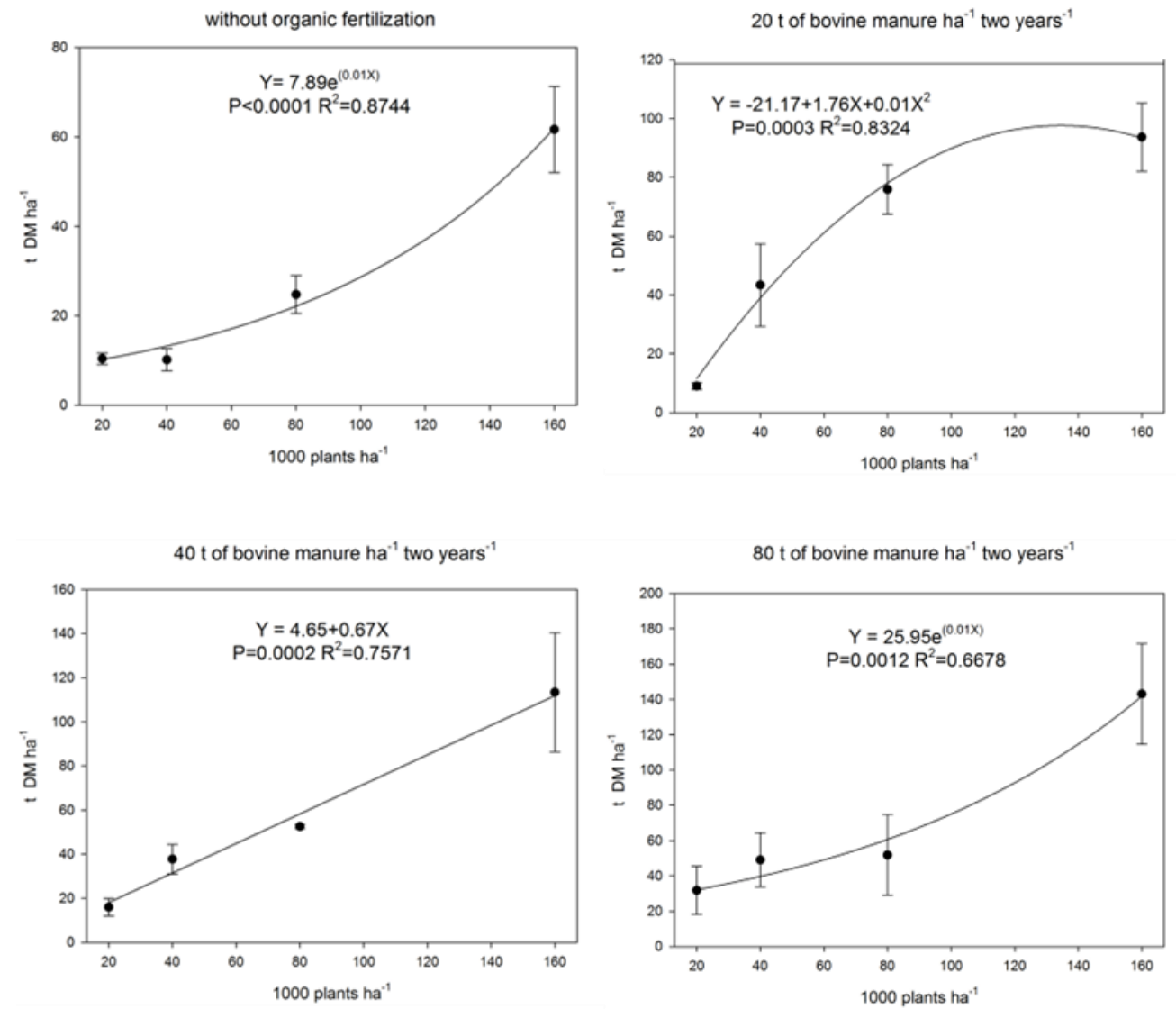

Figure 2. Productivity ( $\mathrm{t} \mathrm{DM} \mathrm{ha} \mathrm{a}^{-1}$ two years ${ }^{-1}$ ) of cactus pear Clone IPA -20, under different planting densities and organic fertilization doses.

On the other hand, it is noteworthy that during two years of growth (2007-2009), there was moderate rainfall in almost every month, with a total rainfall of $1,386 \mathrm{~mm}$ at the end of the experimental period (Figure 1), a value higher than the average historic of the city of Caruaru that is less than $600 \mathrm{~mm}$ per year. This high rainfall, outside the historical pattern, may have contributed to faster nutrient release, as well as maintaining soil moisture at adequate levels for growth, because according to Haynes and Williams (1993), the impact of raindrops promotes the physical breakdown of manure, which in turn releases nutrients.

Several studies have shown positive responses of cactus pear productivity for organic fertilization. Alves et al. (2007) working with cactus Gigante cultivar (Opuntia ficus-indica), fertilized with $20 \mathrm{t} \mathrm{DM} \mathrm{ha}^{-1}$ two years ${ }^{-1}$, in São Bento do Una-PE, verified production of $13.26 \mathrm{t} \mathrm{DM} \mathrm{ha}^{-1}$ year $^{-1}$ in cacti of 19 years old, by maintaining the second order cladodes in crops. Thus, the appropriate application of organic fertilizer ensures the productivity of cacti for many years. Gomes (2011), studying different levels of organic fertilization $\left(0,30\right.$ and $60 \mathrm{t} \mathrm{DM} \mathrm{ha}^{-1}$ years ${ }^{-1}$ ), found an increase in the productivity of cactus pear by enhancing organic fertilization levels.

For the absent of organic fertilization, increased productivity was found with enhanced plant density. This finding was unexpected because in high-density plantations, there is competition between plants requiring higher fertilization levels for nutrients. Such results can be explained by the application of organic fertilizer on plots six years before the experimental harvest (Table 1).

It was also found that treatment with $20 \mathrm{t} \mathrm{DM} \mathrm{ha}^{-1}$ two years ${ }^{-1}$ is not recommended for population densities up to 80,000 plants $\mathrm{ha}^{-1}$, since the curve showed a linear behavior until this population and then grown in decreasing rates until production decrease (Figure 2). Such behavior shows that the fertilization level of $20 \mathrm{t} \mathrm{DM} \mathrm{ha}^{-1}$ two years ${ }^{-1}$ does not meet the crop needs as planting density increases.

A different behavior was observed when it was performed a fertilization with $40 \mathrm{t} \mathrm{DM} \mathrm{ha}^{-1}$ two years $^{-1}$ that showed meet the needs of up to 160,000 plants $\mathrm{ha}^{-1}$. In contrast, the level of $80 \mathrm{t} \mathrm{DM} \mathrm{ha}^{-1}$ two years ${ }^{-1}$ has resulted in similar yields for the 20, 40 and 80 thousand plants $\mathrm{ha}^{-1}$ populations. The high fertilizer dose in these plant populations may have promoted a nutritional imbalance, affecting the productivity of plants. For the population of 160,000 plants, this did not occur due to higher competition between plants.

The reason for the increased productivity due to planting density (Figure 2) can be justified by the higher number of plants per unit area that may possibly have favored an increase in cladode area index (CAI). Dubeux Jr. et al. (2006) found that cacti with populations of 40,000 plants $\mathrm{ha}^{-1}$ showed higher 
CAI (1.02) compared with stands of 5,000 plants/ha (0.26), resulting in the production of up to 33.7 and $17 \mathrm{t} \mathrm{DM} \mathrm{ha}^{-1}$ two year ${ }^{-1}$, respectively. According to Lira et al. (2006), low CAI of cactus pear can be partially reduced by higher plant density or less frequent harvest.

According to Sales et al. (2013), dense crops, if properly managed, have increased absorption of sunlight and photosynthetic efficiency and lower action of weeds contributing to increased productivity, when compared to traditional crops, with smaller plant population.

A significant effect $(\mathrm{P}<0.05)$ of the interaction between fertilization and planting densities was observed on the efficiency of organic fertilization (Figure 3). A positive quadratic linear and exponential behavior for 20, 40 and $80 \mathrm{t}$ bovine manure ha ${ }^{-1}$ two years ${ }^{-1}$ is observed, respectively.
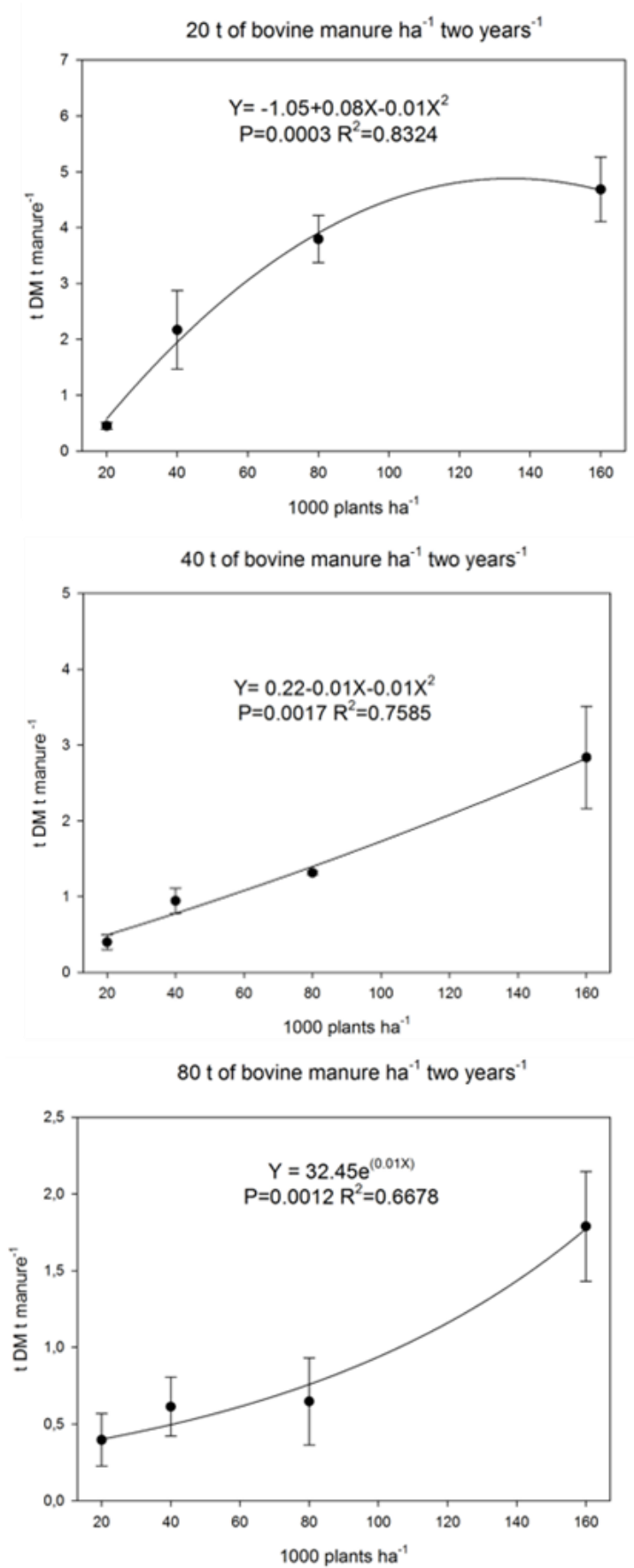

Figure 3. The efficiency of organic fertilization ( $t \mathrm{DM} t$ of cattle manure ${ }^{-1}$ ) in forage cactus Clone IPA -20 , under different doses of organic fertilization and planting densities.

It was found that organic fertilization efficiency decreased with an increase in dose. On the other hand, it was observed that the efficiency was higher in more density plantations, except for the 
level of $20 \mathrm{t}$ of manure, in which there was a decrease in the curve with the use of higher plant density.

Possibly, the reduction of organic fertilization efficiency with increased dose may be associated with a higher amount of nutrients deposited in soil; thus, plants were not stimulated to develop morph physiological mechanisms for searching for nutrients for survival purposes.

For the dose of $20 \mathrm{t}$ of bovine manure/ha/two years, the efficiency was $3.8 \mathrm{t}$ of DM t of bovine manure $^{-1}$ until 80,000 plants $\mathrm{ha}^{-1}$, however, it is observed that the efficiency curve shows decreasing behavior by using 160,000 plants $\mathrm{ha}^{-1}$ (Figure 3). According to Teles et al. (2002), extraction of soil nutrients is higher in density plantations. Thus, higher plant densities require larger fertilizer applications because there is competition for nutrients between plants at these densities.

In this sense, it is recommended that the dose of organic fertilization should be established based not only on soil fertility analysis, in the production purpose and cultivar, but also by planting density, which will be determined by the producer as their forage needs.

No significant interaction between fertilization and planting density on yield of cladodeplants was observed $(\mathrm{P}>0.05)$ after six years of planting. A significant effect $(\mathrm{P}<0.05)$ was observed only for planting density (Figure 4); the associated curve presented exponential behavior.

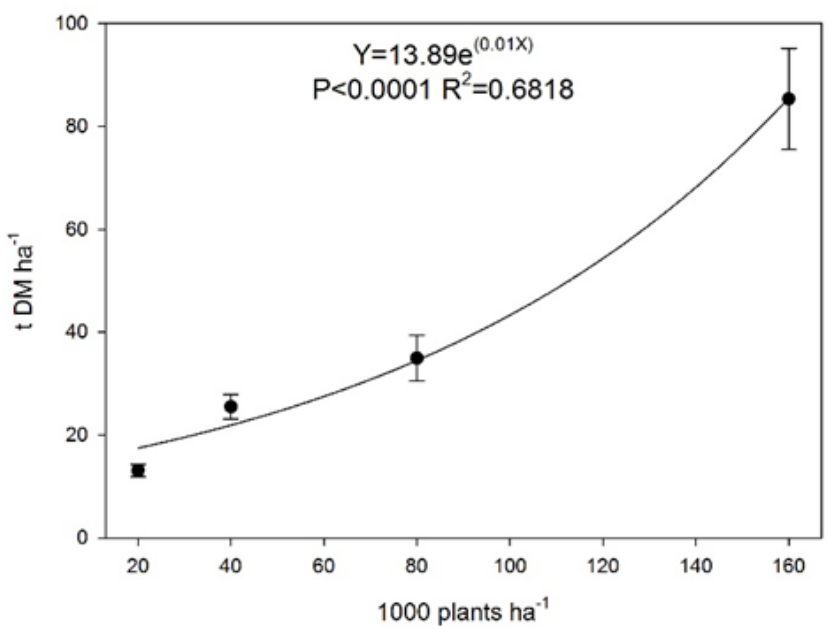

Figure 4. Productivity cladodes - plant $\left(\mathrm{t} \mathrm{DM} \mathrm{ha}^{-1}\right)$ after six years of planting in different planting densities.

It was observed increase in productivity of the cladode-plant with increased planting density, which can be explained by having a greater number of cultivated plants per unit area. In general, the cladode plants are heavier than the others. It is noteworthy that, in the literature, there is little information about the weight and characterization of the cladode-plant. In the present study, these cladodes remained in growth for six years, once the first two harvests promoted their maintenance, which are older and hence, more fiber.

It is worth mentioning that maintaining cladodes of superior orders (eg .primary, secondary, etc.) promotes higher yields, through increasing the cladodes area index and, consequently, the greater light interception by plant community (FARIAS et al., 2005) as well contribute to greater cactus longevity (ALVES et al., 2007).

According to Pimienta-Barrios et al. (2005), the cladode plant is important for being responsible for the productivity of cactus pear, because in extreme drought conditions, it decreases or stops the emission of primary cladodes, thus, reducing water loss and increasing survival of plants.
No significant effect $(\mathrm{P}>0.05)$ was observed of the interaction between fertilization and planting density on the dry weight of roots, after six years of planting. Significant effect was observed $(\mathrm{P}<0.05)$ only on planting density for this feature (Figure 5).

There was an increase in dry root weight with increasing planting density. This result can be explained by the higher number of cultivated plants by area, resulting thus, in larger amounts of roots. However, the dry weight obtained by isolated plant roots in densities of 80 and 160 thousand plants ha ${ }^{-1}$ were lower than those observed in plants cultivated under densities of 20 and 40 thousand plants $\mathrm{ha}^{-1}$. However, by multiplying root weight by planting density, the root system weight per area was higher at greater planting densities $(80$ and 160 thousand plants $\mathrm{ha}^{-1}$ ).

The greater weight of roots per area is an indicative of growth in this plant part aiming at further soil exploration in the search of nutrients. According to Teles et al. (2004), in cactus pear cultivation at dense spacing, there is a greater extraction of soil nutrients. 


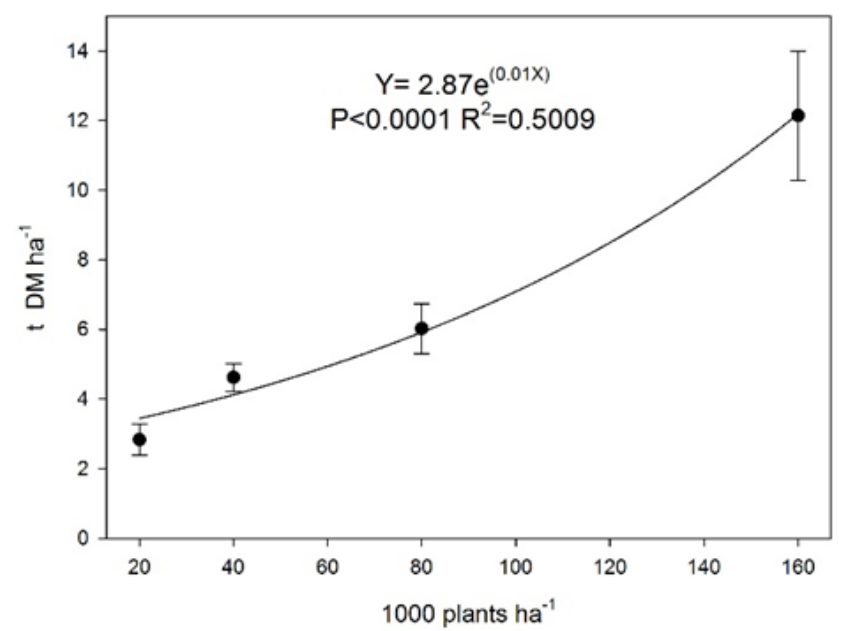

Figure 5. The dry weight of forage cactus roots Clone IPA -20, under different planting densities.

Santos et al. (1994) report that plants with crassulacean acid metabolism have high efficiency with respect to water use by using absorbents to absorb water and nutrients from the soil, losing them during the dry season to prevent the passage of water from roots to soil. In addition, the root system of cactus pear has surface distribution, which facilitates the assimilation of nutrients (CHITEVA; WAIRAGAU, 2013).

It must be emphasized that the difficulty of cactus root system measurements and the lack of such information, as well as the need to measure the length and diameter of roots in future research, contribute to the importance of these root characteristics in the absorption of nutrients.

\section{CONCLUSIONS}

The application of $80 \mathrm{t}$ of bovine manure $\mathrm{ha}^{-1}$ two years ${ }^{-1}$ promotes higher productivity in different planting densities of Clone IPA-20 cactus. The most efficiency of organic fertilization occurs in more dense plantations, except for the level of $20 \mathrm{t}$ of bovine manure ha $^{-1}$ two years ${ }^{-1}$. Higher dry matter yield of cladode-plant and weight of the roots are observed at higher plant densities. For increase cactus productivity, $40 \mathrm{t}$ of bovine manure $\mathrm{ha}^{-1}$ two years $^{-1}$ for plantations with 160,000 plants/ha is recommended.

\section{REFERENCES}

ALMEIDA, J.; PEIXOTO, C.P.; LEDO, C.A.S. Desempenho vegetativo e produtivo da palma forrageira. Enciclopédia Biosfera, Goiânia, v. 8, n. 15, p. $571-581,2012$.

ALVES, R.N. et al. Produção de forragem pela palma após 19 anos sob Diferentes intensidades de corte e espaçamentos. Revista Caatinga, Mossoró, v. 20, n. 4, p. 38-44, 2007.

CHITEVA, R.; WAIRAGAU, N. Chemical and nutritional content of Opuntia ficus-indica (L.). African Journal of Biotechnology, Nairobi, v. 12, n. 21, p. 3309-3312, 2013.

CUNHA, D. N. F. et al. Morfometria e acumulo de biomassa em palma forrageira sob doses de nitrogênio. Revista Brasileira de Saúde e Produção Animal, Salvador, v. 13, n. 14, p. 1156-1165, 2012.

DUBEUX JÚNIOR., J.C.B et al. Productivity of Opuntia ficus-indica (L.) Miller under different N and $\mathrm{P}$ fertilization and plant population in north-east Brazil. Journal of Arid Environments, Amsterdam, v. 67 , n. 3 , p. $357-372,2006$.

EMBRAPA. Sistemas brasileiros de classificação dos solos. 2. ed. Rio de Janeiro, RJ: EMBRAPA-SPI, 2013. 353 p.

FARIAS, I.; SANTOS, D.C.; DUBEUX JÚNIOR., J.C.B. Estabelecimento e manejo da palma forrageira. In: MENEZES, R.S.C.; SIMÕES, D.A.; SAMPAIO, E.V.S.B. (Eds.). A palma no nordeste do Brasil conhecimento atual e novas perspectivas de uso. Recife: Editora Universitária UFPE, 2005. v. único, cap. 6, p. 81-103.

GEBRESAMUEL, N.; GEBRE-MARIAM, T. Comparative Physico-Chemical characterization of the mucilages of two cactus pears (Opuntia sp.) obtained from mekelle, northern Ethiopia. Journal of Biomaterials and Nonobiotechnology, Ireland, v. 3, n. 1, p. 79-86, 2012.

GOMES, J.B. Adubação orgânica na produção de palma forrageira (Opuntia ficus-indica mill.) no Cariri Paraibano. 2011. 50 f. Dissertação (Mestrado em Zootecnia: àrea de Concetração em 
Forragicultura) - Universidade Federal de Campina Grande, Patos, 2011.

HAYNES, R. J.; WILLIAMS, P. H. Nutrient cycling and fertility in the grazed pasture ecosystem. Advances in Agronomy, New York, v. 49, n. 1, p. 119-199, 1993.

LIGUORI, $\mathrm{G}$ et al. $\mathrm{CO}_{2}$ uptake of Opuntia ficus-indica (L.) Mill. whole trees and single cladodes, in relation to plant water status and cladode age. Italian Journal of Agronomy, Monaco, v. 8, n. 3, p. 14-20, 2013.

LIRA, M.A et al. Forage production system: alternatives for sustainability of livestock. Brazilian Journal of Animal Science, Viçosa, v. 35, Sup., p. 491-511, 2006.

MATALLO JÚNIOR., CASAS-CASTAÑEDA, F.; MIGONGO-BAKE, E. Use of lives fences of nopal (Opuntia) and associated crops to rehabilitate and protect sloping land in loja, Ecuador. Mountain Research and Development, Nevada, v. 22, n. 1, p. 22-25, 2002.

MINISTÉRIO DA INTEGRAÇÃO NACIONAL. Nova delimitação do semi-árido brasileiro. 1. ed. Brasília, DF: Secretaria de Políticas de Desenvolvimento Regional, 2006. 35 p.

PEIXOTO, M.J.A et al. Desenvolvimento de Opuntia ficus-indica (L.) Mill., em diferentes substratos, após micro-propagação in vitro. Acta Scientiarum, Maringá, v. 28, n. 1, p. 17-20, 2006.

PIMENTA-BARRIOS, E. et al. Young Daughter Cladodes Affect CO2 Uptake by Mother Cladodes of Opuntia ficus-indica. Annals of Botany, London, v. 95, n. 2, p. 363-369, 2005.

RAMOS, J.P.F. et al. Crescimento vegetativo de Opuntia fícus-indica em diferentes espaçamentos de plantio. Revista Caatinga, Mossoró, v. 24, n. 3, p. 41-48, 2011.

RIVERA, G. et al. Edaphical Characteristics of Three Vegetable Cactus Pear Orchards (Opuntia Ficus-indica) Fertilized with High Amounts of Dairy Manure at Milpa Alta, Mexico. In: V INTERNATIONAL CONGRESS ON CACTUS PEAR AND COCHINEAL, 5., 2006, Champingo. Anais... Chapingo: CAU, 2006. p. 323-333.

SÁ, L.B.; RICHÉ, G.R.; FOTIUS, G.A. As paisagens e o processo de degradação do semiárido nordestino. In: SILVA, J.M.C. et al. (Ed.). Biodiversidade da caatinga: áreas e ações prioritárias para a conservação. Brasília: Ministério do Meio Ambiente, 2004. v. único, cap. 14, p. 17-36.
SAENZ, C. Case studies on agro-industrial utilization of Opuntia species in several countries. In.: SAENZ, C. et al. (Eds.). Agro-industrial utilization of cactus pear. Rome: Food and Agriculture Organization of the United, 2013. v. único, cap. 9, p.111-122.

SALES, A. T. et al. Crescimento vegetativo da palma forrageira em diferentes densidades de plantio no Curimatú paraibano. Tecnologia e Ciência Agropecuária, João Pessoa, v. 7, n. 1, p. 19-24, 2013.

SANTOS, D.C. et al. Estimativas de parâmetros genéticos em clones de palma forrageira Opuntia ficus indica Mill. e Nopalea cochenillifera Salm-Dyck. Pesquisa Agropecuária Brasileira, Brasília, v .29, n. 12, p.1947-1957, 1994.

SAS Inst.Inc.SAS statistics user's guide. Release version 6. SAS Ins. Inc., Cary, NC. 1999.

TELES, M.M. et al. Effects of fertilizer and nematicide on growth and production of cactus pear (Opuntia ficus indica Mill) cv. Gigante. Brazilian Journal of Animal Science, Viçosa, v. 31, n. 1, p. 52-60, 2002.

TELES, M.M. et al Effect of fertilizer and nematicide use of the chemical composition of cactus pear (Opuntia ficus indica Mill). Brazilian Journal of Animal Science, Viçosa, v. 33, n. 6, p. 1992-1998, 2004. 